\title{
SPECTRUM AND FREQUENCY OF THE GJB2 GENE MUTATIONS AMONG LATVIAN PATIENTS WITH PRELINGUAL NONSYNDROMIC HEARING LOSS
}

\author{
Olga Šterna*, Natālija Proṇina*, leva Grïnfelde*, Sandra Kušk̦e**, \\ Astrīda Krūmin, ${ }^{\star \star *}$, Rita Lugovska*, and Aigars Pētersons ${ }^{\star \star \star}$ \\ * Clinic of Medical Genetics, Children's Clinical University Hospital, Juglas iela 20, Rìga, LV-1079, LATVIA; \\ e-mail: dnalab @ bkus.Iv \\ ** Centre for Hearing Impaired Children of Latvia, Lielvārdes iela 68/1, Rīga, LV-1006, LATVIA \\ *** Rīga Stradinš̌ University, Dzirciema iela 16, Rīga, LV-1007, LATVIA
}

Communicated by Andrejs Ërglis

\begin{abstract}
Mutations in the GJB2 gene (connexin 26) are the most common cause of congenital nonsyndromic severe-to-profound hearing loss. Sixty-five hearing impaired probands from Latvia were tested for mutations in the GJB2 gene to determine the percentage of hearing loss attributed to connexin 26 and the types of mutations in this population. A total of $62 \%$ of patients tested had GJB2 mutations. Four different mutations in the GJB2 gene were identified in Latvian patients with nonsyndromic sensorineural hearing loss: 35delG, 311-324del14, 235delC and M34T. The most prevalent mutation is $35 \mathrm{delG}$ (47\% of all probands were homozygous and $8 \%$ compound heterozygous). Our findings support the conclusion that the 35delG mutation is the most prevalent GJB2 mutation and that it is the common cause of hereditary nonsyndromic hearing loss in populations of European descent.
\end{abstract}

Key words: hearing loss, GJB2, connexon, gap junction, DFNB1 - deafness autosomal recessive type 1.

\section{INTRODUCTION}

Hearing loss is the most common birth defect and affects about 1 in 500 newborns (Morton and Nance, 2006). It is the most frequent sensory defect and has significant effect on life quality. Hearing is critical to the normal development and acquisition of language. Prelingual hearing loss is either present at birth or begins before the age of five years, when language has normally been acquired. Hearing loss is a highly heterogeneous disease with many diverse causes. In developed countries about $60 \%$ of the prelingual cases are of genetic origin and $40 \%$ are due to environmental causes (prenatal infections, prematurity, bacterial meningitis, ototoxic drugs are the most frequent ones of them) (Petit et al., 2001). Hearing impairment can be classified according to the degree of severity of the hearing loss for the better hearing ear: mild (hearing level is $26-40 \mathrm{~dB}$ ), moderate $(41-55 \mathrm{~dB})$, moderately severe $(56-70 \mathrm{~dB})$, severe (71-90 dB) and profound ( $\geq 90 \mathrm{~dB}$ ) (Smith and Van Camp, 2008). The various forms of deafness are divided in two categories, syndromic and nonsyndromic (isolated). Syndromic deafness contributes to about $30 \%$ of the cases of prelingual deafness. Syndromic disorders are those where hearing impairment is not the only clinical feature. More than 300 different syndromes (Alport, Pendred, Treacher
Collins, Usher, Waardenburg, etc.), where hearing loss is one of the clinical manifestations, have been identified (Petit et al., 2001; Anonymous, 2009).

The majority of hereditary deafness cases $(\sim 70 \%)$ are nonsyndromic, where hearing deficit is the only clinical sign. Up to date, more than 140 nonsyndromic deafness loci have been reported (Van Camp and Smith, 2009). Nonsyndromic hearing loss is categorised by the mode of inheritance. Approximately, $75 \%$ of non-syndromic hearing loss cases have an autosomal recessive mode of inheritance (DFNB loci), $\sim 20 \%$ autosomal dominant (DFNA loci), 2\% X-linked (DFNX loci), and $1 \%$ to modifier (DFNM loci), Y-linked (DFNY loci) and mitochondrial inheritance each (Feldmann et al., 2004, Van Camp and Smith, 2009). The first locus for an autosomal recessive form of deafness DFNB1 (MIM 220290) was mapped to chromosomal region 13q12-13 (Guilford et al., 1994).

Presently, 26 genes responsible for autosomal recessive hearing loss have been identified, but most of them are causative in only a small percentage of patients. However, one particular gene GJB2, which corresponds to DFNB1 locus, was found to be responsible for up to $50 \%$ of the cases with autosomal recessive nonsyndromic hearing loss. Gene 
GJB2 encodes connexion 26, a gap junction protein $\beta-2$. Connexin 26 is one member of a family of more than 20 related gap junction channel (connexons) forming proteins. All connexins have a common structure with four transmembrane domains, two extracellular loops, one intracellular loop and C- and N-terminal ends (Fig. 1) (Petit et al., 2001; Anonymous, 2009). Most cell types express more than one connexin species, which can form homomeric or heteromeric connexons. Intercellular channels in the auditory system are formed predominantly by connexion 26 but also by connexins 30 and 31 . Connexin 26 has an important role in maintaining a high extracellular electrical potential in the cochlea by recycling of $\mathrm{K}^{+}$ions back to endolymph following depolarization hair cells (Falk and Gilula, 1998; Petit et al., 2001).

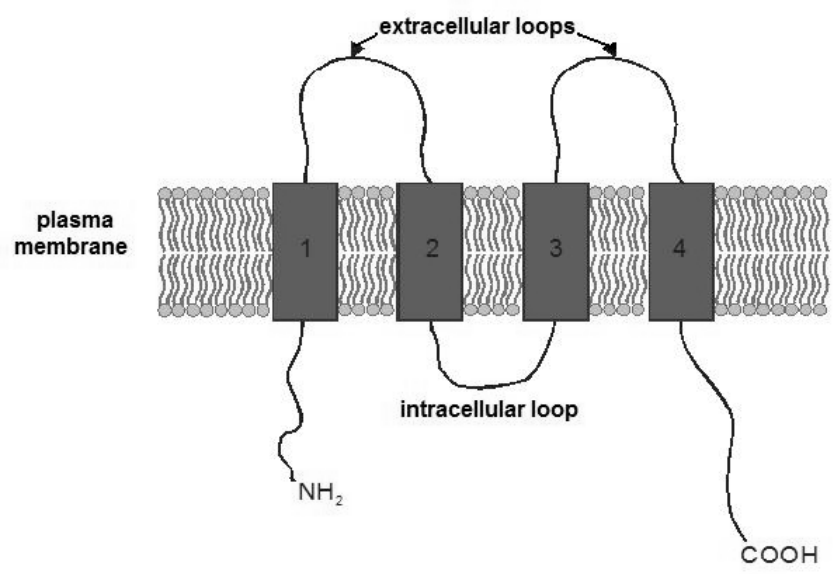

Fig. 1. Representation of the structure of connexins. Numbers 1 to 4 mark transmembrane domains.

Since the GJB2 gene was discovered in 1997 (Kelsell et al., 1997), more than 110 mutations have been identified (mostly missense and frameshift in-dels). The majority (92) of all GJB2 mutations are recessive, and the nature of ten mutations still remains unknown (Ballana et al., 2009). Although most mutations are not very frequent, one recessive mutation named $35 \mathrm{delG}$ has been found in more than $50 \%$ patients of Caucasian origin (Gasparini et al., 2000). This mutation deletes a guanine residue $(\mathrm{G})$ in a sequence of six $\mathrm{G}$ extending from nucleotide position 30 to 35 which results in a premature stop codon at codon position 13 (Petit et al., 2001). The frequency of mutation $35 \mathrm{delG}$ among nonsyndromic hearing loss patients in Croatia, Italy, Spain, Greece, Turkey, France and Austria varies between 51.8\% and 93\% (Denoyelle et al., 1997; Estivill et al., 1998; Antoniadi et al., 2000; Baris et al., 2001; Frei et al., 2002; Pampanos et al., 2002; Roux et al., 2004; Sansovic et al., 2005). In Estonia, the mutation $35 \mathrm{delG}$ accounts up to $45 \%$ of prelingual nonsyndromic hearing loss cases (Teek et al., 2006). Mutation $35 \mathrm{delG}$ is responsible for $10 \%$ of all childhood hearing impairments and for $20 \%$ of hereditary hearing loss (if all environmental causes are excluded) (Kelley et al., 1998).

Carrier frequencies in Europe range from 0.5-4.5\%, with the highest frequencies found in Estonia (Gasparini et al., 2000).
Two other mutations are particularly frequent in specific populations. The $167 \mathrm{delT}$ mutation is most frequent in Ashkenazi Jewish hearing impaired patients. This mutation deletes a thymine $(\mathrm{T})$ residue in nucleotide position 167 , which results in reading frame shifting and premature stop codon at codon position 56. The carrier frequency of this mutation among Ashkenazi Jews is reported to be 4\% (Morell et al., 1998).

The mutation $235 \mathrm{delC}$ is common among hearing loss patients in Japan, Korea and China. This mutation deletes a cytosine (C) residue in a nucleotide position 235 , which results in a reading frame shifting and premature stop codon at codon position 78. The carrier frequency of this mutation in China and Taiwan is estimated at 1-2.8\% (Liu et al., 2002, Hwa et al., 2003). In European populations this mutation is rare.

The phenotype of the GJB2 induced hearing impairment is variable even for the members of one family (Smith and Van Camp 2008). The degree of severity of deafness associated with GJB2 defect varies from mild to profound (Petit et al., 2001).

Lerer et al. (2001) reported a large deletion, named $\operatorname{del}(G J B 6-\mathrm{D} 13 \mathrm{~S} 1830)$, in the DFNB1 locus that truncates gene GJB6 encoding connexin30. It was suggested that this recessive mutation caused hearing loss in individuals that are double heterozygous for the deletion and mutation in the GJB2 gene, either due to a digenic mode of inheritance or because the deletion abolishes control elements that are important in the expression of GJB2 since both genes are close to each other on chromosome 13q12 (Castillo et al., 2002). In 2005, another GJB6 truncating deletion del(GJB6-D13S1854) was reported (Fig. 2) (Castillo et al., 2005). The aim of our paper was to find spectrum and frequency of the GJB2 gene mutations in patients with prelingual nonsyndromic hearing loss in Latvia.

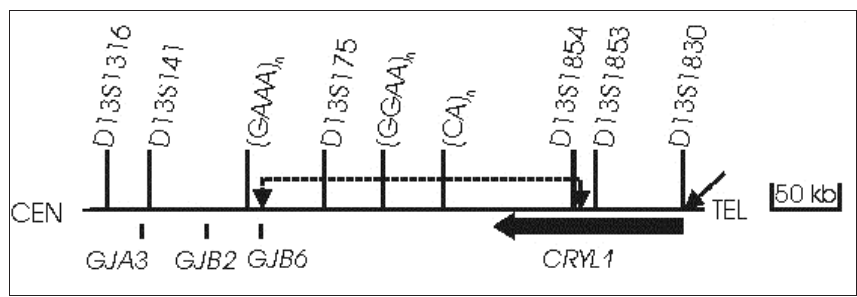

Fig. 2. Map of a $600 \mathrm{~kb}$ DNA segment on chromosome region $13 \mathrm{q} 12$ including the DFNB1 locus that contains genes GJB2 and GJB6. Vertical bars above the map indicate the positions of polymorphic genetic markers. Genes in the region are depicted as vertical bars and arrow below the map. The two breakpoints of the del(GJB6-D13S1854) mutation are marked by vertical arrows, and the extent of the deletion is indicated by a dashed line. The single arrow indicates the distal breakpoint of the $\operatorname{del}(G J B 6-\mathrm{D} 13 \mathrm{~S} 1830)$ mutation.

\section{MATERIALS AND METHODS}

We obtained DNA samples from Latvian patients with prelingual moderately severe to profound sensorineural hearing loss in whom syndromic forms and environmental 
causes of deafness had been excluded; their relatives and individuals with hearing loss positive family history. Blood samples were obtained after obtaining written informed consent in accordance with regulations of the Central Medical Ethics Committee.

Genomic DNA was extracted by standard procedure from peripheral blood leucocytes.

Mutation 35delG was tested in all samples by a method previously described (Simsek et al., 2001). Genomic DNA was amplified by PCR, following enzymatic digestion with restriction endonuclease $M v a \mathrm{I}$. The wild-type $89 \mathrm{bp}$ fragment yielded two digested fragments of 80 and 29 bp. A mutation eliminates the $M v a \mathrm{I}$ site, thus the mutant 88 bp fragment remains uncut.

Samples with no or heterozygous mutation $35 \mathrm{delG}$ were screened for other mutations in the GJB2 gene exon 2 by the automated sequencing method (Wu et al., 2002). The open reading frame of the GJB2 gene was amplified from genomic DNA. Prior to cycle sequencing, PCR products were purified on Montage ${ }^{\mathrm{TM}}$ columns following the manufacturer's instructions ("Millipore", USA). The amplicons were sequenced using two partially overlapping sets of primers: first set from the initial amplification of whole open reading frame and second internal primers. Sequencing was performed using ABI PRISM BigDye Terminator Cycle Sequencing kit v.3.1 on an ABI310 Genetic Analyzer (Applied Biosystems, USA).

Samples that had only one detected mutation in GJB2 had been tested for $\operatorname{del}(G J B 6-\mathrm{D} 13 \mathrm{~S} 1830)$ and $\operatorname{del}(G J B 6-\mathrm{D} 13 \mathrm{~S} 1854)$ using multiplex PCR assay (del Castillo et al., 2005). Genomic DNA was amplified using three sets of primers for the $\operatorname{del}(G J B 6-\mathrm{D} 13 \mathrm{~S} 1830)$ breakpoint junction fragment, the $\operatorname{del}(G J B 6-\mathrm{D} 13 \mathrm{~S} 1854)$ breakpoint junction fragment and for the fragment of GJB6 exon 1 (to obtain a product in case of no deletion occurred). In case of wild type allele only 333 bp GJB6 exon 1 fragment is amplified, del(GJB6-D13S1830) yielded 460 bp junction fragment and $\operatorname{del}(G J B 6-D 13 S 1854)$ yielded 564 bp junction fragment.

\section{RESULTS}

A total of 65 unrelated patients from Latvia who had bilateral moderately severe to profound prelingual nonsyndromic hearing loss, 79 of their relatives and seven individuals with a hearing loss positive family history were screened for the mutation $35 \mathrm{delG}$ in GJB2. For those probands who were found to be heterozygous or normal for mutation 35delG, the coding region of the gene was sequenced and examined.

Among the GJB2 mutations in 65 probands (total of 130 chromosomes) we identified 77 mutated alleles.

Forty of the 65 probands $(62 \%)$ carried mutations in GJB2, including 31 homozygotes for mutation $35 \mathrm{delG}$ (47\%), four compound heterozygotes for mutations $35 \mathrm{delG}$ and 311324del14 (6\%), one compound heterozygote for mutations $35 \mathrm{delG}$ and $235 \mathrm{delC}(2 \%)$, one compound heterozygote for mutations 35delG and M34T (2\%), two heterozygotes for mutation M34T (3\%) and one heterozygote for mutation 35 delG $(2 \%)$.

Two causative GJB2 mutations were found in 37 patients (56\%), 25 patients had no GJB2 mutations (38\%), three patients were heterozygous for one GJB2 mutation (6\%) and the cause of impairment remained unclear.

Patients with only one GJB2 mutation identified were tested for two deletions that truncate gene GJB6: $\operatorname{del}(G J B 6-\mathrm{D} 13 \mathrm{~S} 1830)$ and $\operatorname{del}(G J B 6-\mathrm{D} 13 \mathrm{~S} 1854)$. No deletions were found.

Four of five affected relatives of the screened probands were found to be $35 \mathrm{delG}$ homozygotes, one case was detected prenatally. One affected relative is $35 \mathrm{delG}$ and 311 324del14 compound heterozygote. Forty-one from 74 unaffected relatives of the patients were determined to be $35 \mathrm{delG}$ carriers, two were $235 \mathrm{delC}$ carriers and one has a311-324del14 mutation. Thirty unaffected relatives had no mutations in the GJB2 gene.

Seven unaffected individuals with a positive family history were tested for mutations in GJB2. Two of them were found to be GJB2 mutation carriers: one for mutation $35 \mathrm{delG}$ and one for mutation 51del12insA.

Four different mutations in the GJB2 gene were identified in Latvian patients with nonsyndromic sensorineural hearing loss: 35delG, 311-324del14, 235delC and M34T. One heterozygous 51del12ins A mutation was identified in an unaffected individual with positive family history (Table 1).

All probands with biallelic truncating mutations in GJB2 have severe or profound hearing loss, and the proband whose genotype was 35delG/M34T had moderate hearing loss. Probands with no or one GJB2 mutation had moderate to profound hearing loss.

FREQUENCIES AND CHARACTERISATION OF MUTATIONS FOUND IN GENE GJB2

\begin{tabular}{lcc|c|c}
\hline \multicolumn{1}{c|}{ Mutation name } & Codon number & Nucleotide change & Mutation character & Frequency among patients \\
\hline 35delG & 10 & ATCCTGGGGGgTG & frameshift, nonsense \\
311-324del14 & 103 & AGAggaagttcatcaagGGGGA & frameshift, nonsense \\
235delC & 77 & ATGGGCcCTGC & frameshift, nonsense \\
M34T & 34 & ATG $\rightarrow$ ACG & missense \\
51del12insA & 17 & TC(del)caccagcattgg(ins)aAA & frameshift, nonsense
\end{tabular}




\section{DISCUSSION}

The aim of this study was to determine the spectrum and frequency of the GJB2 gene mutations among Latvian patients with prelingual nonsyndromic hearing loss. Our study included patients with moderately severe to profound hearing loss.

Studies in many countries have shown that mutation in the GJB2 gene is the major cause of the nonsyndromic prelingual hearing loss. About $60 \%$ of deafness is due to genetic factors and $\sim 20 \%$ of all hereditary cases are caused by mutations in the GJB2 gene. By the end of 2008, there were 6,000 hearing loss patients registered at the Centre for Hearing Impaired Children of Latvia. GJB2 mutations might be the cause of impairment for about 1,200 of them. Unfortunately, there is a high level of resistance from patients and their relatives to participate in genetic studies. The consanguineous marriage is frequent among the people with hearing loss; they become a part of the so-called "deaf culture and think that their culture will be threatened by genetic studies. That is why our study group was rather small, which hampered a statistical analysis of the acquired data.

All patients were clinically classified by a referring physician. The age of the hearing loss diagnosis established varied from four months to three years. Sixty-five prelingual nonsyndromic hearing loss patients referred by Centre for Hearing Impaired Children of Latvia were tested to determine whether the GJB2 gene mutation was responsible for their disease.

Five different GJB2 genotypes were identified:

- 31 patients (47\%) had genotype 35delG/35delG

- 4 patients (6\%) had genotype 35delG/311-324del14

- 1 patient (2\%) had genotype 35delG/235delC

- 1 patient (2\%) had genotype 35delG/M34T

- 2 patients (3\%) havd genotype M34T/N or X

- 1 patient (2\%) had genotype $35 \mathrm{delG} / \mathrm{N}$ or $\mathrm{X}$

- 25 patients $(38 \%)$ had no mutations in the GJB2 gene.

Our data shows that the GJB2 mutations are a significant cause of nonsyndromic hearing loss in Latvia (62\% of patients have GJB2 mutations). The most frequent GJB2 mutation is $35 \mathrm{delG}$, of which $47 \%$ represented homozygous and $10 \%$ compound heterozygous cases. This is consistent with previous studies about the incidence and frequencies of the $35 \mathrm{delG}$ mutation (53.8-93\%) in nonsyndromic hearing loss patients in European and American populations (Denoyelle et al., 1997; Estivill et al., 1998; Cohn et al., 1999; Green et al., 1999; Antoniadi et al., 2000; Baris et al., 2001; Frei et al., 2002; Orzan et al., 2002; Roux et al., 2004; Sansovic et al., 2005).

All patients with biallelic deletions that truncate the synthesis of polypeptide and inactivate connexin 26 (genotypes
35delG/35delG, 35delG/235delC，35delG/311-324del14) have bilateral prelingual stable nonsyndromic hearing loss; the degree of severity varies from severe to profound. Our results are consistent with previously reported data (Snoeckx et al., 2005). Five patients had delayed speech development that maybe due to late diagnosis. One patient with genotype $35 \mathrm{delG} / 35 \mathrm{delG}$ had a vestibular disorder. Previous clinical study about phenotype correlation with mutations in GJB2 identified that there is no associations between these mutations and vestibular defects (Cohn and Kelley 2000), which indicated another cause for this impairment.

One proband with a genotype of 35delG/M34T had moderate hearing loss. Mutation M34T is a missense mutation, it does not inactivate connexin 26, but reduces its activity. Current studies show that M34T causes a milder form of nonsyndromic recessive hearing loss and that it is not a common cause of severe-to-profound hearing loss (Snoeckx et al., 2005).

Patients with no or one GJB2 mutation identified have moderate to profound hearing loss.

This study has direct clinical implication for the genetic counselling of hearing impaired patients. The challenge that remains is to identify the cause of the disease for 28 individuals screened who had one or no GJB2 mutations. In our study we followed the testing strategy available at OMIM, where the first step is to detect mutations in the exon 2 of $G J B 2$, and in case of only one GJB2 mutation found, the second step is to detect GJB6 deletions, $\operatorname{del}(G J B 6-D 13 S 1830)$ and $\operatorname{del}(G J B 6-\mathrm{D} 13 \mathrm{~S} 1854)$.

Testing for DFNB1 mutations is the first step in identifying the cause of prelingual nonsyndromic hearing loss. A positive result for biallelic DFNB1 mutations in the DFNB1 should eliminate the need for expensive tests such as electroretinography and others, therefore, significantly reducing medical costs. Genotype data allow geneticists, physicians and audiologists to counsel affected individuals and their relatives more appropriately and to predict the risk to the future generations. A molecular diagnostic facility for DFNB1 mutation screening made prenatal testing available.

\section{AKNOWLEDGEMENTS}

The work was supported by the National Research Programme in Medicine 2006-2009, No. 6, "Decreasing children's mortality, increasing life expectancy and improving life quality - development of high-technology based diagnostic and treatment algorithms of inherited pathologies" and by grant No. 05.0023 from the Latvian Council of Science.

\section{REFERENCES}

Anonymous (2009). Online Mendelian Inheritance in Man, OMIM (TM). McKusick-Nathans Institute of Genetic Medicine, Johns Hopkins University (Baltimore, MD) and National Center for Biotechnology Information, 
National Library of Medicine (Bethesda, MD), 2009. http://www.ncbi.nlm.nih.gov/omim/

Antoniadi, T., Gronskov, K., Sand A., Pampanos, A., Brondum-Nielsen, K., Petersen, M.B. (2000). Mutation analysis of the GJB2 (connexin 26) gene by DGGE in Greek patients with sensorineural deafness. Hum Mutat., 16(1), 7-12.

Ballana, E., Ventayol, M., Rabionet, R., Gasparini, P., Estivill, X. (2009). Connexins and deafness http://www.crg.es/deafness

Baris I., Kilinc M.O., Tolun A. (2001). Frequency of the 35delG mutation in the connexin 26 gene in Turkish hearing-impaired patients. Clinical Genet., 60 (6), 452-455.

del Castillo, I., Villamar, M., Moreno-Pelayo, M.A., del Castillo, F.J., Alvarez, A., Tellería, D., Menéndez, I., Moreno, F. (2002). A deletion involving the connexin 30 gene in nonsyndromic hearing impairment. New Engl. J. Med., 24; 346(4), 243-249.

del Castillo, F.J., Rodríguez-Ballesteros, M., Alvarez A., Hutchin, T., Leonard, E., de Oliveira, C.A., Azaiez, H., Brownstein, Z., Avenarius, M.R., Marlin, S., Pandya, A., Shahin, H., Siemering, K.R., Weil, D., Wuyts, W., Aguirre, L.A., Martín, Y., Moreno-Pelayo, M.A., Villamar, M., Avraham, K.B., Dahl, H-H. M., Kanaan, M., Nance, W.E., Petit, C., Smith, R.J.H., Van Camp, G., Sartorato, E.L., Murgia, A., Moreno, F., del Castillo, I. (2005). A novel deletion involving the connexin-30 gene, del(GJB6-d13s1854), found in trans with mutations in the GJB2 gene (connexin-26) in subjects with DFNB1 non-syndromic hearing impairment. J. Med. Gen., 42(7), 588-594.

Cohn, E.S., Kelley, P.M. (2000). Clinical phenotype and mutations in connexin 26 (DFNB1/GJB2), the most common cause of childhood hearing loss. Amer. J. Hum. Genet., 89(3), 130-136.

Denoyelle, F., Weil, D., Maw, M.A., Wilcox, S.A., Lench, N.J., Allen-Powell, D.R., Osborn, A.H., Dahl, H.H., Middleton, A., Houseman, M.J., Dode, C., Marlin, S., Boulila-ElGaied, A., Grati, M., Ayadi, H., BenArab, S., Bitoun, P., Lina-Granade, G., Godet, J., Mustapha, M., Loiselet, J., El-Zir, E., Aubois, A., Joannard, A., Petit, C., et al. (1997). Prelingual deafness: High prevalence of a $30 \mathrm{delG}$ mutation in the connexin 26 gene. Hum. Mol. Genet., 6(12), 2173-2177.

Estivill, X., Fortina, P., Surrey, S., Rabionet, R., Melchionda, S., D'Agruma, L., Mansfield, E., Rappaport, E., Govea, N., Milàf, M., Zelante, L., Gasparini, P. (1998). Connexin-26 mutations in sporadic and inherited sensorineural deafness. Lancet, 351, 394-398.

Falk, M.M., Gilula, N.B. (1998). Connexin membrane protein biosynthesis is influenced by polypeptide positioning within the translocon and signal peptidase access. J. Biol. Chem., 273(14), 7856-7864.

Feldmann, D., Denoyelle, F., Chauvin, P., Garabedian, E.N., Couderc, R., Odent, S., Joannard, A., Schmerber, S., Delobel, B., Lema, J., Journel, H., Catros, H., Marechal, C.L., Dollfus, H., Eliot, M.M., Delaunoy, J.P., David, A., Calai, C., Drouin-Garraud, V., Obstoy, M.F., Bouccara, D., Sterkers, O., Huy, P.T., Goizet, C., Duriez, F., Fellmann, F., Helias, J., Vigneron, J. Montaut, B., Lewin, P., Petit, C., Marlin, S. (2004). Large deletion of the GJB6 gene in deaf patients heterozygous for the GJB2 gene mutation: Genotypic and phenotypic analysis. Amer. J. Med. Genet., 127A(3), 263-267.

Frei, K., Szuhai, K., Lucas, T., Weipoltshammer, K., Schofer, C., Ramsebner, R., Baumgartner, W.D., Raap, A.K., Bittner, R., Wachtler, F.J., Kirschhofer, K. (2002). Connexin 26 mutations in cases of sensorineural deafness in eastern Austria. Eur. J. Hum. Genet., 10(7), $427-432$

Gasparini, P., Rabionet, R., Barbujani, G., Melchionda, S., Petersen, M., Brondum-Nielsen, K., Metspalu, A., Oitmaa, E., Pisano, M., Fortina, P., Zelante, L., Estivill, X. (2000). High carrier frequency of the 35 delG deafness mutation in European populations. Genetic Analysis Consortium of GJB2 35delG. Eur. J. Hum. Genet., 8(1), 19-23.

Green, G.E., Scott, D.A., McDonald, J.M., Woodworth, G.G., Sheffield, V.C., Smith, R.J. (1999). Carrier rates in the midwestern United States for GJB2 mutations causing inherited deafness. JAMA, 281(23), 2211-2216.
Guilford, P., Ben Arab, S., Blanchard, S., Levilliers, J., Weissenbach, J., Belkahia, A., Petit, C. (1994). A non-syndromic form of neurosensory, recessive deafness maps to the pericentromeric region of chromosome $13 \mathrm{q}$. Nature Genet., 6, 24-28.

Hwa, H.L., Ko, T.M., Hsu, C.J., Huang, C.H., Chiang, Y.L., Oong, J.L., Chen, C.C., Hsu, C.K. (2003). Mutation spectrum of the connexin 26 (GJB2) gene in Taiwanese patients with prelingual deafness. Genet. Med., 5(3), 161-165

Kelley, P.M., Harris, D.J., Comer, B.C., Askew, J.W., Fowler, T., Smith, S.D., Kimberling, W.J. (1998). Novel mutations in the connexin 26 gene $(G J B 2)$ that cause autosomal recessive (DFNB1) hearing loss. Amer. J. Hum. Genet., 62(4), 792-799.

Kelsell, D.P., Dunlop, J., Stevens, H.P., Lench, N.J., Liang, J.N., Parry, G., Mueller, R.F., Leigh, I.M. (1997). Connexin 26 mutations in hereditary non-syndromic sensorineural deafness. Nature, 387, 80-83.

Lerer, I., Sagi, M., Ben-Neriah, Z., Wang, T., Levi, H., Abeliovich, D. (2001). A deletion mutation in $G J B 6$ cooperating with a GJB2 mutation in trans in non-syndromic deafness: A novel founder mutation in Ashkenazi Jews. Hum. Mutat., 18, 460-460.

Liu, X.Z., Xia, X.J., Ke, X.M., Ouyang, X.M., Du, L.L., Liu, Y.H., Angeli, S., Telischi, F.F., Nance, W.E., Balkany, T., Xu, L.R. (2002). The prevalence of connexin 26 (GJB2) mutations in the Chinese population. Hum. Genet., 111(4-5), 394-397.

Morell, R.J., Kim, H.J., Hood, L.J., Goforth, L., Friderici, K., Fisher, R., Van Camp, G., Berlin, C.I., Oddoux, C., Ostrer, H., Keats, B., Friedman, T.B. (1998). Mutations in the connexin 26 gene (GJB2) among Ashkenazi Jews with nonsyndromic recessive deafness. New Engl. J. Med., 339(21), 1500-1555.

Morton, C.C., Nance. W.E. (2006). Newborn hearing screening — a silent revolution. New Engl. J. Med., 354, 2151-2164.

Orzan, E., Murgia, A., Polli, R., Martella, M., Mazza, A., Zacchello, F., Babighian, G. (2002). Connexin 26 preverbal hearing impairment: Mutation prevalence and heterozygosity in a selected population. Int. J. Audiol., 41(2), 120-124.

Pampanos, A., Economides, J., Iliadou, V., Neou, P., Leotsakos, P., Voyiatzis, N., Eleftheriades, N., Tsakanikos, M., Antoniadi, T., Hatzaki, A., Konstantopoulou, I., Yannoukakos, D., Gronskov, K., Brondum-Nielsen, K., Grigoriadou, M., Gyftodimou, J., Iliades, T., Skevas, A., Petersen, M.B. (2002). Prevalence of GJB2 mutations in prelingual deafness in the Greek population. Int. J. Pediatr. Otorhinolaryngol., 65(2), 101-108.

Petit, C., Levilliers, J., Marlin, S., Hardelin, J.-P. (2001). Hereditary Hearing Loss. In: The Metabolic and Molecular Basis of Inherited Disease. 8th ed. (pp. 6281-6328). Scriver, C.R., Beaudet, A.L., Sly, W.S., Valle, D. (eds.). New York: McGraw-Hill.

Roux, A.F., Pallares-Ruiz, N., Vielle, A., Faugère, V., Templin, C., Leprevost, D., Artières, F., Lina, G., Molinari, N., Blanche, P., Mondain, M., Claustres, M. (2004). Molecular epidemiology of DFNB1 deafness in France. BMC Med. Genet., 5, 5.

Sansovic, I., Knezevic, J., Matijevic, T., Balen, S., Barisic, I., Pavelic, J. (2005). Prevalence of the $35 \mathrm{delG}$ mutation in the GJB2 gene of patients with nonsyndromic hearing loss from Croatia. Genet. Test., 9(4), 297-300.

Simsek, M., Al-Wardy, N., Al-Khabory, M. (2001). A polimerase chain reaction - restriction fragment length polymorphism (PCR - RFLP) test to detect the common mutation (35delG) in the connexin-26 gene. SQU J. Sci. Res.: Med. Sci., 1, 9-12.

Smith, R.J., Van Camp, G. (2008). Nonsyndromic Hearing Loss and Deafness, DFNB1,

http://www.ncbi.nlm.nih.gov/bookshelf/br.fcgi?book=gene\&part=dfnb1.

Snoeckx, R.L., Huygen, P.L., Feldmann, D. et al. (2005). GJB2 mutations and degree of hearing loss: A multicenter study. Amer. J. Hum. Genet., 77(6), 945-957.

Teek, R., Rukas, E., Oitmaa, E., Kruustuk, K., Zordania, R., Joost, K., Schrijver, I., Gardner, P., Kull, M., Ounap, K. (2006). The genetic testing 
of early onset hereditary hearing loss among Estonian children. Labor. Med., 29(1), 105.

Van Camp, G, Smith, R.J.H. (2009). Hereditary Hearing Loss Homepage. http://webh01.ua.ac.be/hhh/

Received 11 July 2009
Wu, B.L., Lindeman, N., Lip, V., Adams, A., Amato, R.S., Cox, G., Irons, M., Kenn, M., Korf, B., Raisen, J., Platt, O. (2002). Effectiveness of sequencing connexin 26 (GJB2) in cases of familial or sporadic childhood deafness referred for molecular diagnostic testing. Genet. Med., 4(4), 279-288.

GĒNA GJB2 MUTĀCIJU SPEKTRS UN BIEŽUMS LATVIJAS PACIENTIEM AR PRELINGVĀLO NESINDROMĀLO VĀJDZIRDĪBU

Gēna GJB2 mutācijas ir visbiežākais iemesls nesindromāliem sensoneirāliem dzirdes traucējumiem dažādās populācijās. Pētījumā tika veiktas analīzes 65 Latvijas Dzirdes centra pacientiem ar nesindromālo vājdzirdību, ar mērḳi noteikt mutācijas gēnā GJB2 un noskaidrot šo mutāciju spektru un sastopamības biežumu. 62\% izmeklēto pacientu tika atrastas mutācijas gēnā GJB2. Latvijas pacientiem ar nesindromālo vājdzirdību ir atrastas četras mutācijas: 35delG, 311-324del14, 235delC un M34T. Biežākā gēna GJB2 mutācija Latvijas pacientiem ar nesindromālo vājdzirdību ir 35delG (47\% ir homozigoti un $8 \%$ ir kompaunda heterozigoti). Mūsu dati sakrīt ar citu pêtījumu rezultātiem, ka mutācija 35delG ir biežākā mutācija GJB2 gēnā un ir visizplatîtākais vājdzirdības iemesls Eiropas populācijās. 